\title{
Research of Sustainable Use of Tire Shreds in Landfill
}

\author{
Kristina Bazienė and Rasa Vaiškūnaitė * \\ Department of Environmental Protection, Faculty of Environmental Engineering, Vilnius Gediminas Technical \\ University, Sauletekio av. 11, Vilnius LT-10223, Lithuania; kristina.baziene@vgtu.lt \\ * Correspondence: rasa.vaiskunaite@vgtu.lt; Tel.: +370-274-50-90
}

Academic Editor: Marc A. Rosen

Received: 10 March 2016; Accepted: 4 August 2016; Published: 8 August 2016

\begin{abstract}
Studies are on-going to establish the suitability of tire shreds in the landfill bottom drainage layer, to minimize clogging. Four experimental columns were constructed in which were $500 \mathrm{~mm}$ long and $200 \mathrm{~mm}$ in diameter. They were filled with different fillers and with a different amount of tire shreds. The most important problem with drainage filler in landfills is clogging. Over long periods of time in landfill operation, the drainage layer clogs (the pores of the layer become smaller and the porosity of the layer becomes smaller). The experiment was carried out for 365 days. Although the landfill for this period represents only one-fiftieth or less of the operation time, the laboratory tests found that the drainage layer bandwidth of reduction in one year can have a negative impact in the long run over time. The main elements that influence the decrease of conductivity are the total suspended solids and calcium and iron compounds. The change of these compounds was observed during the column study, where the concentration of each month in all the columns was decreasing. The results showed that the waste of rubber (tire shreds) used for creating fillers in columns provided greater porosity of the layer. It is a beneficial reason to use a rubble and tire shreds waste mix for forming the drainage layer in landfills.
\end{abstract}

Keywords: landfill leachate; sustainability of tired shreds; drainage clogging

\section{Introduction}

The use of tire shred waste as a by-product material is now widely recognized as one of the major preferred options for the achievement of sustainable development. The environmental policies require the waste to be reused and be managed according to circular economy principles. The main approach allows end-of-life products to be used in processing technology and gives them the resources necessary to investigate fringe-recycling methods of issues relating to the achievement of the next generation of sustainable product reuse [1-7]. Waste management is one of the main discussed issues worldwide, including in Lithuania. Modern municipal waste landfills have been operating in Lithuania since 2007. Before 2007, all waste was dumped in the landfills, which were not equipped with leachate or gas collection systems. Therefore, leachate and gas found their way into the surrounding environment [8-12]. The use of as many recycling materials as possible is an important point. The use of tire shreds for the formation of a landfill drainage layer is one of the options widely studied by scientists from Canada, the United Kingdom and Germany [13,14].

In recent years, tire shreds applied for landfill drainage have been given global attention from some of the world's studies. Nevertheless, uncertainty regarding landfill bottom drainage layers formed from tire shreds remains a relevant issue. Fleming and Rowe [15-17] and Paksy et al. [18] have researched the reasons for the clogging of the drainage layer with chemically and biologically mediated deposits. However, the process of how the clogging of biological and chemical origin takes place with waste materials in landfills still has not been properly investigated to have the right answer. It is considered to be both environmentally and economically useful to use tire shreds as landfill drainage 
material. Water that percolates through waste from precipitation, irrigation and waste biodegradation leaches contaminants from refuse, thus generating a fluid called leachate. The composition of waste affects the composition of leachate. Field and laboratory studies on leachate drainage systems [15] have shown that clogging of drainage and filter materials occurs due to the accumulation of material within the pore space of drainage media, resulting in a decrease in porosity and hydraulic conductivity. Several studies have approved the appropriateness of tires as a landfill drainage material $[18,19]$. However, these tests are usually conducted for short periods of time using methanogenic leachate. However, the composition of leachate that passes through the leachate collection system combined with the presence of microbial activity results in chemically and biologically induced clogging [15]. The development of clogging decreases the pore space available for transporting and selecting leachate, reduces the hydraulic conductivity of the drainage layer, and consequently reduces the efficiency and period of effective functioning of the leachate drainage system. Since these systems may be required to collect and remove leachate for extended periods of time, it is important to design them with an optimum long-term performance life. Fleming et al. [20] and Paksy et al. [18] conducted lab research on the chemical and biological clogging of drainage layers that might occur during the lifetime of landfill. Research conducted in Canada indicates that tire shreds are more susceptible than gravel to clogging in a saturated drainage area and will not be as effective as drainage layers after a relatively short time. The studies on landfill design highlight the main problems encountered during the operation of landfill. The different composition of leachate has an impact on clogging processes in the landfill drainage layer.

Clogging can be a result of landslides, washings and other negative processes affecting the natural environment. Currently, the landfill drainage layer is used for forming rubble that is $32-65 \mathrm{~mm}$ in diameter. Rowe et al. [1] presented the findings from the early stages of this ongoing investigation. They observed a decrease of calcium in the concentrations of leachate between the influents and effluents of column tests. They also noted a linear relationship between the total chemical oxygen demand (COD) and dissolved calcium in both raw leachate and partially treated leachate effluent from laboratory columns. Van Gulck et al. [19] described the chemistry of these columns and implications for combined clogging with the pre-treatment of leachate. The landfill drainage layer is required as a filter, which helps with reducing the risk in surrounding landfill areas. One of the widely concerning problems dealing with the drainage layer is using recyclable materials for drainable formation [21]. Construction wastes are not applied for the drainage layer because of a high content of calcium carbonate, which increases the possibility of clogging processes. The studies performed by the world's scientists show that calcium carbonate, silica and iron compounds dominate in the clogging process [12,22-29]. These elements are not the main pollutants of leachate, but they form the main compounds, which pollute the landfill leachate collection system. The changes in the amounts of total suspended solids and calcium and iron compounds in the landfill leachate are improving; a part of these compounds' sediments are found in the drainage layer and pollute the landfill leachate collecting system. Lead, cadmium, arsenic and copper are the main important pollutants of the landfill leachate, but compounds of these elements are not important for the leachate collection system's permeability. The main pollutants of landfill leachate can make an impact on the surrounding environment in the case of landfill leachate collection disruption (an effluence of the leachate though the mass of waste or a waste landfill landslide of waste mass). The material forming a bottom drainage layer must be made of appropriate matter and meet the requirements for pressure. A pressure of $200 \mathrm{kPa}$ for a drainage layer for 20 meters of waste mass can be observed. However, material fractions less than $32 \mathrm{~mm}$ in diameter cannot be used. The particle sizes of tire shreds making the fractions of 50-100 $\mathrm{mm}$ can be used for forming the landfill bottom drainage layer. The main objectives of this study include:

- $\quad$ analysis of the changes of the leachate concentration of calcium, total suspended solids (TSS) and iron, and their dependence on the composition of the different tire shred layers in the fillers;

- evaluation of the complex impact of different drainage layers on the clogged landfill drainage layer. 
The objectives of the manuscript set in European legislation (the European Union Landfill Directive 1999/31/EC) have been key drivers for improving waste management, stimulating innovation in recycling, limiting the use of landfilling, and creating incentives to change consumer behaviour [30]. If we re-manufacture, reuse and recycle, and if one industry's waste becomes another's raw materials, we can move to a more circular economy where waste is eliminated and resources are used in an efficient and sustainable way. On 2 December 2015, the European Commission adopted a legislative proposal and annex to review waste-related targets in the Landfill Directive 1999/31/EC. One of the goals for the 2030 AGENDA for Sustainable Development of the United Nations is, by 2020, to achieve the environmentally sound management of wastes throughout their life cycle and significantly reduce their release into air, water and soil in order to minimize their adverse impacts on human health and the environment.

\section{Materials and Methods}

The biggest regional landfill is situated in the Kazokiškès district close to the city of Vilnius (in Lithuania). This landfill conforms to the EU regulations. Vilnius is the biggest city in Lithuania and has a population of more than 650,000 inhabitants. Waste from the whole region goes to the Kazokiškes landfill, making up to 20,000 tonnes per month. Leachate for the performed experiment was taken from this landfill, which has been operated from 2007. Leachate was from "young" landfill and very concentrated with different compounds and had a high effect on the clogging processes. The effect of rainwater on a deposited waste layer occurs when humidity reaches $45 \%$, which in practice means that $13.5 \mathrm{~cm}$ of water/meter waste is absorbed before the formation of leachate and it depends on the initial humidity of landfill waste [12].

An experimental stand was mounted in a polyvinyl chloride (PVC) plastic pipe having a diameter of $200 \mathrm{~mm}$ and a length of $500 \mathrm{~mm}$. The bottom of the drainage layer has a support grid with a pore diameter of $2 \mathrm{~mm}$. The whole column of a filled drainage layer stands on both sides of the tightly closed container. The process of the inflow and outflow of leachate takes place in pipes. The laboratory test was made applying two different drainage layers. Laboratory column tests were carried out to evaluate clogging under controlled conditions (Figure 1).

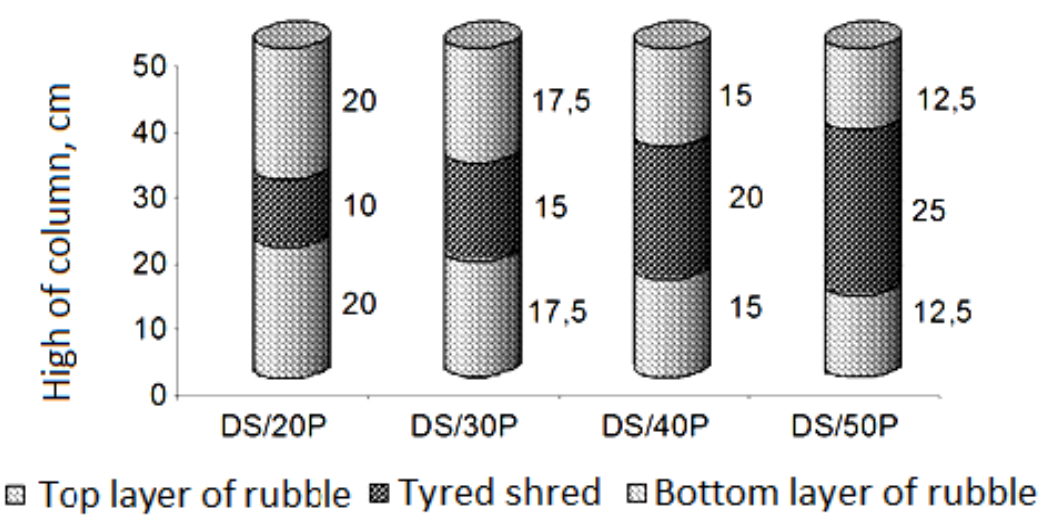

Figure 1. Scheme of drainage rubble and tire shreds layout (DS/20P-80\% of drainage rubble and $20 \%$ of tire shreds; DS $/ 30 \mathrm{P}-70 \%$ of drainage rubble and $30 \%$ of tire shreds; DS $/ 40 \mathrm{P}-60 \%$ of drainage rubble and $40 \%$ of tire shreds; DS $/ 50 \mathrm{P}-50 \%$ of drainage rubble and $50 \%$ of tire shreds).

The drainage layer is formed of three parts: (a) column 1 is made of $40 \%$ of drainage rubble, $20 \%$ of tire shreds and $40 \%$ of drainage rubble; (b) column $2-35 \%$ of drainage rubble, $30 \%$ of tire shreds and $35 \%$ of drainage; (c) column $3-30 \%$ of drainage rubble, $40 \%$ of tire shreds and $30 \%$ of drainage; (d) column $4-25 \%$ of drainage rubble, $50 \%$ of tire shreds and $25 \%$ of drainage.

Drainage porosity will be lower than the actual porosity as a result of incomplete draining of leachate under gravity due to the fluid adhering to drainage medium and clog material. 
Drainage porosity was measured before and after the laboratory column test. An important point is the evaluation of the porosity of the drainage layer in the study on clogging, because accumulation on the porous media causes changes in the conductivity of the drainage layer. Thus, it is important to assess the porosity of judging the level of clogging. In case of high porosity, drainage layer aeration is good enough and moisture cannot accumulate, because precipitation over a large space quickly runs off into collection pipes.

Statistical analysis ANOVA was applied to verify the normal distribution of the experimental data. This research work looked at how to further evaluate the material (tire shreds) that minimizes the clogging processes of the landfill drainage layer. The change of concentrations in percentage was calculated for each parameter in all columns together for making a statistical analysis and a comparison of laboratory experimental data [13].

\section{Results}

The porosity of the created layer was measured before starting a laboratory test on clogging. The porosity of the drainage rubble was $37 \%$ and that of the tire shreds was $58 \%$ (Table 1 ). The different porosity of each layer was measured after 365 days of research. Some Canadian scientists [26] established that clogging processes started from the top of all columns. Analyzing data from the Table 1, it confirms that the clogging begins with the first layer, where leachate comes into contact with solid drainage material.

Table 1. Porosity of different layers before and after clogging column test.

\begin{tabular}{lcccccc}
\hline \multirow{2}{*}{ Material } & \multirow{2}{*}{ Before Test (\%) } & \multicolumn{4}{c}{ Following 365 Days from the Test (\%) } \\
\cline { 3 - 7 } & & Column 1 & Column 2 & Column 3 & Column 4 & Column 5 \\
\hline Drainage rubble at the top of column & 37 & 34 & 34 & 35 & 35 \\
Layer of tire shreds & 58 & 56 & 56 & 57 & 56 & 56 \\
Drainage rubble at the bottom of column & 37 & 35 & 35 & 36 & 35 & 35 \\
\hline
\end{tabular}

Municipal landfill leachate is rich in large quantities of various compounds. On contact with the drainage layer, formed precipitation is deposited on the particle surface that causes clogging. Tire shreds used for layers increase porosity and hence reduce the possibility of clogging. Although tire shreds are at a high pressure of $200 \mathrm{kPa}$, it is still not sufficient. When hydraulic conductivity is $0.3 \mathrm{~m} / \mathrm{s}$, slower precipitation takes place on solid surfaces of drainage material. An increase in the amount of tire shreds leads to a higher compression of all drainage layers. Forming a drainage layer, Canadian researchers [26] propose using less than $40 \%$ of the whole amount of the drainage layer. British scientists were testing tire shreds of different sizes. Those studies showed that the application of tire shreds caused no obstruction and was a very suitable material for the use of formatting the landfill drainage layer [22].

Additionally, calcium is probably a constituent of extracellular polysaccharides and proteins used as linking materials for the granulation of microorganisms. The observations of column tests display the process of how the layer of tire shreds is clogged and point out the main parameters determining the changes. The content of the total suspended solids (TSS) changed very little for the period of the conducted investigations and varied from 254 to $225 \mathrm{mg} / \mathrm{L}$ (11\% of the total amount) in column DS40/P for the period of 365 days (Figure 2).

Similar changes of TSS were found in the column with $20 \%$ of tire shreds, from 254 to $220 \mathrm{mg} / \mathrm{L}$. The amount of TSS in leachate in other columns changed more, from 254 to $200 \mathrm{mg} / \mathrm{L}$. The biggest changes of TSS in the leachate were measured after 183 days (half of the test period) in all columns. The bacteria in the drainage filler has to accumulate over a period from three to six months (based on several conditions), which was the reason for the decrease of the amount of total suspended solids. Figure 2 shows the downward trend in all columns in the concentration of TSS which could be influenced by the wider space between particles or different positions of the tire shreds. 
Thus, precipitated biomass, which was found in the drainage material, may contain some calcium. Changes in the calcium concentration were about $12 \mathrm{mg} / \mathrm{L}(2.5 \%$ of the total amount) for the period of 365 days in different columns. Analyzing changes of concentration in leachate leaching through different fillers, we observed a general trend-the biggest decrease of the amount of calcium in leachate was after three months in all columns. It can be due to the fact that the beginning of the clogging processes during the first three months was the most intensive time for using the most useful nutrients and creating the best conditions for existence.

The situation describing changes in the concentration of iron is different. The amount of iron concentration (Figure 2) decreased by $2 \mathrm{mg} / \mathrm{L}$ (which made it 30\% of the total amount) for the period of 365 days, while the iron concentration in the leachate was only $6.4 \mathrm{mg} / \mathrm{L}$. These are the biggest changes taking into account all investigated elements. The obtained data show that calcium was affected more significantly.
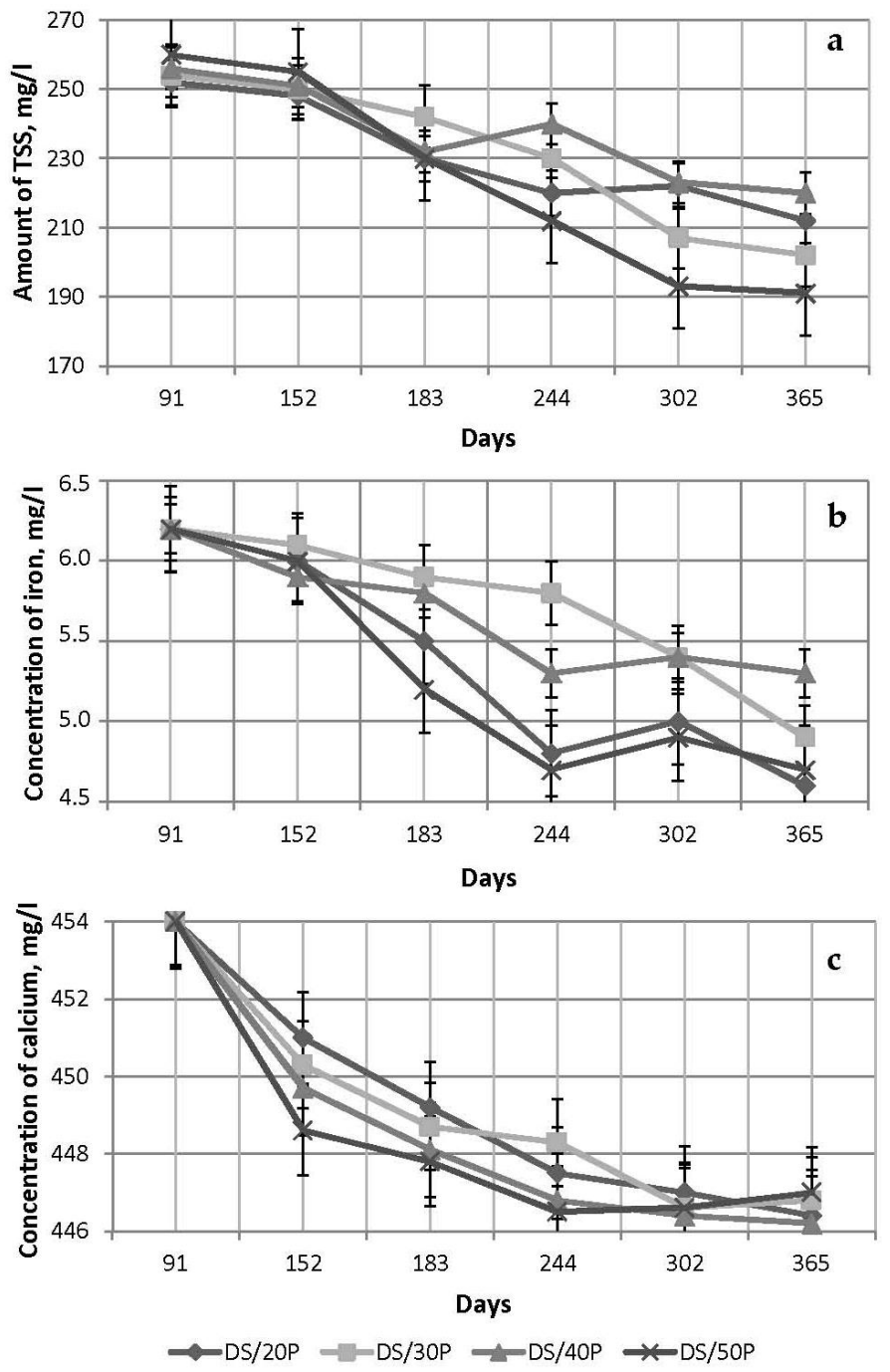

Figure 2. Changes of concentration of TSS (a) and iron (b) and calcium (c) in leachate over 365 days (DS $/ 20 \mathrm{P}-80 \%$ of drainage rubble and $20 \%$ of tire shreds; DS $/ 30 \mathrm{P}-70 \%$ of drainage rubble and $30 \%$ of tire shreds; DS $/ 40 \mathrm{P}-60 \%$ of drainage rubble and $40 \%$ of tire shreds; DS $/ 50 \mathrm{P}-50 \%$ of drainage rubble and $50 \%$ of tire shreds).

Comparing the amount of the three elements in the leachate, changes in calcium were not as high as those in iron and TSS due to the fact that calcium participates in biological processes, which continue a longer period. Iron and TSS involved more in the physical- chemical processes, that are 
significantly shorter compared with biological processes. It is important to look at different changes of different column fillers. In trying to find the best amount of tire shreds, it is important to analyze all the fillers' effects on the leachate parameters. The biggest differences in the leachate parameters are the amounts of TSS and iron. The smallest changes of TSS and iron were measured in the column with $40 \%$ of tire shreds. The biggest changes of the leachate were measured in the column with $50 \%$ of tire shreds.

The drainage layer structure developed, intended for the decrease of clogging processes in municipal waste landfill drainage systems, allows for the use of recycled materials (wasted tire shreds). The porosity of landfill drainage system filling composed of rubble and tire shreds is $19 \%$ higher as compared with the porosity of the filling composed of rubble alone. The filling proposed may be employed for the formation of landfill leachate drainage systems, thus efficiently using the tire shreds. Such a filling improves the filtration properties and slows down the clogging. The layer of the tire shreds, inserted into the rubble filling, mitigates the change of the leachate components. The general trend was observed in all samples of leachate passing the columns filled with rubble drainage and a tire shred layer insert.

The experiment was done for 365 days and it takes a very short time of landfill operation. Some investigations have already been done with modeling clogging processes in a drainage layer filled with tire shreds [12,14]. The BIOCLOG model helped to forecast the changes of porosity of different column fillings. The relevant research showed that tire shreds have better results for minimizing clogging processes and effecting the environment less. The usage of tire shreds for the landfill drainage layer is also very important of tire waste reuse processes.

The statistical analysis was done using the analysis of variance calculation. This statistical analysis showed how measured compounds in separate tests have differences. The amounts of all components analyzed were very different. They depend on the composition of the leachate. The amount of calcium is always bigger than that of iron, because the chemical element calcium is more conformable in the world. The percentage change of each compound was used to do the statistical analysis. The date of the statistical analysis (ANOVA) is presented in the table below (Table 2).

Table 2. Results of statistical analysis of the average change of laboratory-tested leachate components.

\begin{tabular}{cccc}
\hline Source & StDev & Var & Skew \\
\hline Group of TSS changes & 6.82 & 46.57 & 0.593 \\
Group of calcium changes & 8.07 & 65.07 & 0.271 \\
Group of iron changes & 1.37 & 3.67 & 0.889 \\
\hline StDev—standard deviation; & Var-variance; Skew - deviation.
\end{tabular}

There was a statistically significant difference between groups (compounds of leachate) as determined by ANOVA $(\mathrm{F}(2,36)=4.94 ; p<0.023)$.

The conductivity decease of drainage systems in municipal waste landfills manifests itself not earlier than after five years of operation or even later, making the modeling of the conductivity decrease so important.

\section{Conclusions}

The research indicated that columns filled with different layers of tire shreds can be the basis for future investigations of the sustainable use of tire shreds in the landfills' bottom drainage formation.

It was discovered that the best filling for porosity is a tire shred and landfill waste rubber blend of $58 \%$. The rubber waste increases the porosity by $21 \%$, from $37 \%$ to $58 \%$. Bigger porous holes between the solid particles allow for the higher percent of porosity.

The smallest changes in TSS and iron were measured in the column with $40 \%$ of tire shreds. In addition, the smallest changes in the porosity of the bottom layer were measured in the column 
with $40 \%$ of tire shreds. This is the most suitable filler for use in formatting the landfill leachate drainage layer.

During the laboratory testing time, the decrease of suspended solids and calcium and iron concentrations in the landfill leachate, passing the column filled with landfill rubble drainage and tire shreds, proved that tire shreds are an efficient material for the installation of the leachate drainage layer in municipal solid waste landfills. The study revealed the possibility for the sustainable use of tire shreds as a reuse material in the landfills and as a reliable material for the drainage system.

Acknowledgments: The research has been funded under the project "Promotion of Student Scientific Activities" (VP1-3.1-ŠMM-01-V-02-003) from the Research Council of Lithuania.

Author Contributions: Kristina Bazienè analyzed the data and wrote this paper. Rasa Vaiškūnaite designed and performed this research. All authors have read and approved the final manuscript.

Conflicts of Interest: The authors declare no conflict of interest.

\section{References}

1. Rahimifard, S.; Coates, G.; Staikos, T.; Edwards, C.; Abu-Bakar, M. Barriers, drivers and challenges for sustainable product recovery and recycling. Int. J. Sustain. Eng. 2009, 2, 80-90. [CrossRef]

2. Torretta, V.; Rada, E.C.; Ragazzi, M.; Trulli, E.; Istrate, I.A.; Cioca, L.I. Treatment and disposal of tyres: Two EU approaches. Rev. Waste Manag. 2015, 45, 152-160. [CrossRef] [PubMed]

3. Zabaniotou, A.A.; Antoniou, N.; Stavropoulos, G. Novel sorbent materials for environmental remediation via depolymerization of used tyres. Desalin. Water Treat. 2015, 56, 1264-1273. [CrossRef]

4. López, F.A.; Centeno, T.A.; Rodríguez, O.; Alguacil, F.J. Preparation and characterization of activated carbon from the char produced in the thermolysis of granulated scrap tyres. J. Air Waste Manag. Assoc. 2013, 63, 534-544. [CrossRef] [PubMed]

5. Rada, E.C.; Ragazzi, M.; Dal Maschio, R.; Ischia, M.; Panaitescu, V.N. Energy recovery from tyres waste through thermal option. UPB Sci. Bull. Ser. D 2012, 74, 201-210.

6. Grigiante, M.; Ischia, M.; Baratieri, M.; Maschio, R.D.; Ragazzi, M. Pyrolysis analysis and solid residue stabilization of polymers, waste tyres, spruce sawdust and sewage sludge. Waste Biomass Valoriz. 2010, 1, 381-393. [CrossRef]

7. Karagiannidis, A.; Kasampalis, T. Resource recovery from end-of-life tyres in Greece: A field survey, state-of-art and trends. Waste Manag. Res. 2010, 28, 520-532. [CrossRef] [PubMed]

8. Alkalay, L.D.; Guerrero, J.M.; Lema, R.; Chamy, M.R. Anaerobic treatment of municipal sanitary landfill leachates: The problem of refractory and toxic components. World J. Microbiol. Biotechnol. 1998, 14, 309-320. [CrossRef]

9. Jaskelevičius, B.; Lynikienė, V. Investigation of influence of Lapes landfill leachate on ground and surface water pollution with heavy metals. J. Environ. Eng. Landsc. Manag. 2009, 17, 131-139. [CrossRef]

10. Westholm, L.J.; Repo, E.; Sillanpää, M. Filter materials for metal removal from mine drainage-A review. Environ. Sci. Pollut. Res. 2014, 21, 9109-9128. [CrossRef] [PubMed]

11. Petraitis, E. Investigation of the Jerubaičiai landfill leachate. Ekologija 2009, 55, 86-92. [CrossRef]

12. Van Gulck, J.F.; Rowe, R.K.; Rittmann, B.E.; Cooke, A.J. Predicting biogeochemical calcium precipitation in landfill leachate collection systems. Biodegradation 2003, 14, 331-346. [CrossRef]

13. Obrien, R.G. A general ANOVA method for robust test of additive models for variances. J. Am. Stat. Assoc. 1979, 74, 877-880. [CrossRef]

14. Baziene, K.; Vasarevicius, S.; Ndeapo, N. Research of landfill drainage layer clogging. In Proceedings of the 9th International Conference “Environmental Engineering”, Vilnius, Lithuania, 22-23 May 2014.

15. Fleming, I.R.; Rowe, R.K. Laboratory studies of clogging of landfill leachate collection and drainage systems. Can. Geotech. J. 2004, 41, 134-153. [CrossRef]

16. Rowe, R.K.; Van Gulck, J.; Millward, S.C. Biologically induced clogging of a granular medium permeated with synthetic leachate. J. Environ. Eng. Sci. 2002, 1, 135-156. [CrossRef]

17. Rowe, R.K. Long-term performance of contaminant barrier systems. 45th Rankine lecture. Geotechnique 2005, 55, 631-678. [CrossRef] 
18. Paksy, A.; Powrie, W.; Robinson, J.P.; Peeling, L. A laboratory investigation of Microbial clogging in granular landfill drainage media. Geotechnique 1998, 43, 389-401. [CrossRef]

19. Rowe, R.K. Short- and long-term leakage through compositeliners. The 7 th Arthur Casagrande Lecture. Can. Geotech. J. 2012, 49, 141-169. [CrossRef]

20. Fleming, I.R.; Rowe, R.K.; Cullimore, D.R. Field observations of clogging in a landfill leachate collection system. Can. Geotech. J. 1999, 36, 289-296. [CrossRef]

21. Ettler, V.; Mihaljevic, M.; Matura, M.; Skalova, M.; Sebek, O.; Bezdicka, P. Termporal variation of trace elements in waters polluted by municipal solid waste landfill leachate. Bull. Environ. Contam. Toxicol. 2008, 80, 274-279. [CrossRef] [PubMed]

22. El-Fadel, M.; Bou-Zeid, E.; Chahina, W.; Alayli, B. Temporal variation of leachate quality from pre-sorted and baled municipal solid waste with high organic and moisture content. Waste Manag. 2002, 22, 269-282. [CrossRef]

23. Koerner, G.R.; Koerner, R.M.; Martin, J.P. Design of landfill leachate collection filters. J. Geotech. Eng. 1994, 120, 1792-1803. [CrossRef]

24. Korfiatis, G.; Demetracopoulos, A.; Bourodimos, E.; Nawy, E. Moisture transport in a solid waste column. J. Environ. Eng. 1984, 110, 789-796. [CrossRef]

25. Maliva, R.G.; Missime, T.M.; Leo, K.C.; Statom, R.A.; Dupraz, C.; Lynn, M.; Dickson, J.A.D. Unusual calcite stromatolites and pisoids from a landfill leachate collection system. Geology 2000, 28, 931-934. [CrossRef]

26. McIsaac, R.; Rowe, R.K. Changes in leachate chemistry and porosity as leachate permeates through tire shreds and gravel. Can. Geotech. J. 2005, 42, 1173-1188. [CrossRef]

27. McIsaac, R.; Rowe, R.K. Clogging of gravel drainage layers permeated with landfill leachate. J. Geotech. Geoenviron. Eng. 2007, 133, 1026-1039. [CrossRef]

28. McIsaac, R.; Rowe, R.K. Effect of filter separators on the clogging of leachate collection systems. Can. Geotech. J. 2008, 43, 674-693. [CrossRef]

29. Zigmontienè, A.; Zuokaitè, E. Investigation into emissions of gaseous pollutants during sewage sludge composting with wood waste. J. Environ. Eng. Landsc. Manag. 2010, 18, 128-136. [CrossRef]

30. Council Directive 1999/31/EC of 26 April 1999 on the landfill of waste. Available online: http:/ / eur-lex. europa.eu/legal-content/en/TXT/?uri=CELEX:31999L0031 (accessed on 5 August 2016).

(C) 2016 by the authors; licensee MDPI, Basel, Switzerland. This article is an open access article distributed under the terms and conditions of the Creative Commons Attribution (CC-BY) license (http://creativecommons.org/licenses/by/4.0/). 